\title{
Virological and clinical characteristics of hepatitis delta virus in South Asia
}

\author{
Khalid Mumtaz ${ }^{1 *}$, Umair S Ahmed ${ }^{1}$, Sadik Memon², Ali Khawaja', Muhammad T Usmani', Tariq Moatter ${ }^{3}$, \\ Saeed Hamid ${ }^{1}$ and Wasim Jafri ${ }^{1}$
}

\begin{abstract}
Background \& Aims: There is a paucity of data on the impact of hepatitis D virus (HDV) in patients with hepatitis $B$ virus (HBV) infection from South Asia. We studied the impact of HDV co-infection on virological and clinical characteristics.
\end{abstract}

Methods: We collected data of 480 patients with HBsAg positive and a detectable HBV DNA PCR, who presented to the Aga Khan University, Karachi and Isra University in Hyderabad, Pakistan in the last 5 years. HDV co-infection was diagnosed on the basis of anti-HDV. ALT, HBeAg, HBeAb and HBV DNA PCR quantitative levels were checked in all patients. We divided all patients into two groups based on anti-HDV, and compared their biochemical, serological \& virological labs and clinical spectrum. Clinical spectrum of disease included asymptomatic carrier (AC), chronic active hepatitis (CAH), immuno-tolerant phase (IP), and compensated cirrhosis (CC).

Results: HDV co-infection was found in 169 (35.2\%). There were 164 (34.6\%) HBeAg positive and 316 (65.4\%) HBeAg negative patients. Mean ALT level was $66 \pm 73$ IU. 233 (48.5\%) had raised ALT. HBV DNA level was $\geq 10 e 5$ in 103(21.5\%) patients. Overall, among HBV/HDV co-infection, 146/169 (86.4\%) had suppressed HBV DNA PCR as compared to 231/311 (74.3\%) patients with HBV mono-infection; $\mathrm{p}$-value $=0.002$. Among HBeAg negative patients 71/128(55.5\%) had raised ALT levels among HBV/HDV co-infection as compared to 71/188 (37.8\%) with HBV monoinfection ( $p$-value $=0.002$ ); levels of HBV DNA were equal in two groups; there were 27/128 (21\%) patients with CC among HBV/HDV co-infection as compared to $23(12 \%)$ in HBV mono-infection ( $p$-value $=0.009$ ); there were less AC ( $p$-value $=0.009)$ and more CAH ( $p$-value $=0.009)$ among HBV/HDV co-infection patients. Among HBeAg positive patients, serum ALT, HBV DNA levels and the spectrum of HBV were similar in the two groups.

Conclusions: HBV/HDV co-infection results in the suppression of HBV DNA. A fair proportion of HBV/HDV coinfected patients with HBeAg negative have active hepatitis B infection and cirrhosis as compared to those with mono-infection.

\section{Introduction}

Hepatitis delta virus (HDV) is a satellite RNA virus that depends on the envelope protein of the hepatitis $B$ virus (HBV) to enter the hepatocytes and assemble new HDV particles [1]. Worldwide, more than 350 million people are considered to have chronic HBV infection, and 1520 million of these individuals are thought to be coinfected or super-infected with HDV [2].

Hepatitis delta is considered to be the most severe form of viral hepatitis, often leading to the rapid

\footnotetext{
* Correspondence: khalid.mumtaz@aku.edu

'Section of Gastroenterology, Department of Medicine, Aga Khan University

Hospital, Stadium Road, PO Box \# 74800, Karachi, Pakistan

Full list of author information is available at the end of the article
}

development of liver cirrhosis. Furthermore HDV infection has also been linked with a higher risk for the development of hepatocellular carcinoma [3].

The infection was endemic in the 1970s throughout Southern Europe, and was responsible for a substantial proportion of cases of HBsAg- positive liver disorders $[4,5]$. However, the prevalence of HDV had substantially declined in Italy from $23 \%$ in 1987 to $8.3 \%$ in 1997 as reported by Stroffolini et al [6]. A similar decline was noted in Taiwan, with prevalence decreasing from 23.7\% in 1983 to 4.2\% in 1996 [7], as well as in Spain and Turkey [8]. This decline in prevalence of HDV infection was achieved by enhancing awareness among the general public and by measures taken for vaccination against
C Biomed Central 
hepatitis B in these countries. In Pakistan, however, viral hepatitis remains a serious health problem. We have reported the country-wide prevalence of HDV infection in hepatitis B surface antigen (HBsAg)-positive individuals to be $16.6 \%$ [9]. Very recently, a comprehensive report on the epidemiology of hepatitis delta in the AsiaPacific region was published by Abbas et al [10]. According to this report, prevalence from different parts of Asia is variable, and ranges from $3-10 \%$ in India, $2-20 \%$ in Iran, $18 \%$ in Afghanistan and 3-8\% in Saudi Arabia.

There are seven HDV genotypes described, and their nomenclature is defined as type I-VII; various genotypes are reported to be associated with different long term outcomes of infection [11]. Recently Moatter et al reported genotype 1 of HDV and genotype D of HBV from Pakistan [12], which has also been confirmed on a larger scale by our group (13).

HBV infection is associated with a broad spectrum of clinical manifestations, ranging from an asymptomatic carrier (AC) state to acute liver failure. It can also manifest in diverse forms of chronic infection, including the immune tolerant phase (IP), chronic active hepatitis $B$ $(\mathrm{CAH})$, compensated liver cirrhosis (CC), and hepatocellular carcinoma (HCC).

Co-infections of hepatitis B with multiple hepatitis viruses are associated with diverse patterns of reciprocal inhibition of viral replication. Delta hepatitis occurs due to co-infection of HBsAg positive patients with hepatitis delta virus. There are inconsistent reports on the role of each virus in the pathogenicity of HBV/HDV infection. Some reports suggest that the activity of liver disease is mainly due to HDV [13-16] while others implicate hepatitis B virus, regardless of the levels of HBV DNA, in the aggressive nature and progression of disease [17]. In studies from Europe, HDV has frequently been shown to suppress HBV replication $[18,19]$, and $70-90 \%$ of patients with hepatitis $D$ are hepatitis $B$ e antigen ( $\mathrm{HBeAg}$ ) negative, with low serum levels of HBV DNA. However, despite this influence of HDV on HBV, 15$30 \%$ of patients with hepatitis D are $\mathrm{HBeAg}$ and/or HBV DNA positive.

There is no data, to our knowledge, on the characteristics and impact of hepatitis delta virus on hepatitis B virus infection and its spectrum of diseases from South Asia. The aim of this study was to investigate the virological and clinical characteristics of patients infected with $\mathrm{HBV} / \mathrm{HDV}$ infection in two large tertiary care centers of Pakistan.

\section{Methods}

\section{Patients' characteristics}

We conducted this study prospectively in patients seen at the Aga Khan University Hospital (AKUH), Karachi and Isra University Hospital, Hyderabad, Pakistan. Both hospitals are situated in the province of Sindh and serve as main tertiary care centers located in the southern part of Pakistan, which is among the largest countries of South Asia; it represents 30\% of the population of this region. Each year approximately half a million patients visit the out-patient clinics and 45,000 are managed as in-patients in the different wards of these two hospitals. The AKUH laboratory has 189 collection centers all around the country including 07 in Hyderabad where the samples are collected and transported to the central laboratory in Karachi for processing.

We identified 2455 HBsAg positive patients and checked their HBV DNA PCR by qualitative methods from 2005 to 2009 at these two centers. Out of 2455 patients with a reactive HBsAg, 480 patients with a positive HBV DNA PCR underwent testing for anti-HDV and quantitative HBV DNA PCR assay. HDV infection was defined by positive anti-HDV results. Demographics and physical findings were recorded in all patients with or without HDV coinfection prior to the start of any anti-viral treatment.

\section{Biochemical and virological markers}

Serum samples of all patients were tested for biochemical parameters including complete blood count, total bilirubin, ALT, alkaline phosphatase, creatinine and prothrombin time (PT), by standard laboratory methods. Upper limit of ALT was $55 \mathrm{IU} / \mathrm{L}$ for men and $33 \mathrm{IU} / \mathrm{L}$ for women. Serological tests conducted were qualitative HBsAg, HB core IgG, HBeAg, anti-HBe, anti-HDV by EIA assay (Chicago, IL, USA) and anti-HCV by ELISA-3 in all included patients during their visits to clinic within six months. All the biochemical, serologic and virological tests from the two centers was processed in the central clinical laboratory at the Aga Khan University Hospital, Karachi.

HBV DNA PCR qualitative analysis was performed by Cobas Amplicor HBV Monitor (Roche Diagnostic Systems, Basel, Switzerland) with a lower detection limit of 500 copies $/ \mathrm{ml}$. We considered the value of the qualitative PCR detectable to be $\leq 10^{2}$. All these patients were subsequently tested for quantitative HBV DNA PCR assay (RoboGene HBV DNA Quantification Kit, TripleHyb version, Leipzig, Delitzscher Str, Germany) and anti-HDV testing. Quantitative HBV DNA PCR has the lower limit of detection of approximately $1000\left(>10^{2}\right)$ copies/ml. HDV RNA PCR qualitative assay (Roche Diagnostics, USA) could only be checked in 49 patients with HDV co-infection as this test was not available in early part of the study in our laboratory.

HDV RNA was isolated from patients' serum samples by High Pure Viral RNA isolation kit, according to the manufacturer's instructions (Roche Diagnostics, USA). RNA was eluted from spin columns provided with the kit in sterile nuclease free water and stored at $-80{ }^{\circ} \mathrm{C}$ until further analysis. Later, RNA samples were reverse 
transcribed into cDNA using 1st Strand cDNA Synthesis Kit for RT-PCR (Roche Diagnostics, USA). Briefly, cDNA mix consisted of reaction buffer containing 5 $\mathrm{mM} \mathrm{MgCl}_{2}$, R NA, random primers, 50 units RNAse inhibitor and AMV reverse transcriptase. The reaction was carried out for $90 \mathrm{~min}$ at $42{ }^{\circ} \mathrm{C}$ in a thermal cycler. The resulting cDNA was amplified with sequence specific primers for HDV. The amplified products were separated on a $1.5 \%$ agarose gel and a 400 bp product indicated the presence of HDV in the sample. To monitor the quality of the assay in each test run, both negative and positive controls were included [20].

Abdominal ultrasound of all included patients was performed for the assessment of echo-texture, size and margins of liver \& spleen and for features suggestive of portal hypertension. Stages of liver disease such as those with or without cirrhosis were identified on clinical and/ or biochemical laboratory parameters along with ultrasonological findings.

\section{Spectrum of hepatitis virus infection}

480 hepatitis B patients with or without HDV infection were categorized into four clinical stages: (1) Asymptomatic carrier (AC) - patients were clinically asymptomatic with hepatitis $\mathrm{B}$ e antigen $(\mathrm{HBeAg})$ negative, serum HBV DNA levels are $<10^{5}$ and normal serum ALT levels (at least 2 ALT values in the previous 6 months follow-up). (2) Immune-tolerant phase (IP) patients were asymptomatic with hepatitis $B$ e antigen (HBeAg) positive or negative, high serum HBV DNA levels $\left(\geq 10^{5}\right)$ and normal serum ALT levels (at least 2 ALT values in the previous 6 months). (3) Chronic active hepatitis B (CAH) - patients may be symptomatic or asymptomatic with hepatitis $B$ e antigen ( $\mathrm{HBeAg}$ ) positive or negative, with raised serum HBV DNA PCR and ALT levels (at least 2 ALT values above ULN in the previous 6 months). These patients have no evidence of cirrhosis on clinical, biochemical laboratory parameters along with ultrasonological examination. (4) Compensated liver cirrhosis (CLC) - patients may be symptomatic or asymptomatic with hepatitis $\mathrm{B}$ e antigen ( $\mathrm{HBeAg}$ ) positive or negative, whatever are their serum HBV DNA levels, and ALT levels in the previous 6 months. These patients have evidence of cirrhosis identified on clinical, and/or biochemical laboratory parameters along with abdominal ultrasound examination $[21,22]$. HDV co-infection-patients with anti-HDV reactive and/or HDV RNA PCR detectable [23].

\section{Exclusion criteria}

We excluded patients (1) under the age of 14 years, (2) with decompensated liver disease (defined by a serum bilirubin more than 2.5 times the upper limit of normal; prothrombin time $>3$ seconds compared with control; serum albumin $<2.5 \mathrm{~g} / \mathrm{dl}$; or a history of ascites, variceal hemorrhage or hepatic encephalopathy or hepatocellular carcinoma (3) with evidence of liver disease due to another etiology such as hepatitis $\mathrm{C}$, metabolic liver disease or autoimmune liver disease, (4) history of use of hepatotoxic drugs and (5) patients with multiple infections (i.e. HBV, HDV, HIV and HCV).

This study was approved by the Ethics Review Committee (ERC) of Aga Khan University Hospital.

\section{Statistical Analysis}

Statistical analysis was performed using the Statistical Package for Social Science SPSS (Release 17.0, standard version, copyright ${ }^{\circ}$ SPSS; 1989-02). Descriptive analysis was performed for demographic and clinical features; results were presented as mean \pm standard deviation for quantitative variables and number (percentages) for qualitative variables.

A descriptive analysis was performed for all patients with $\mathrm{HBsAg}$ positive along with HBV DNA PCR detectable. To determine any statistical difference, data were divided into $\mathrm{HBeAg}$ positive and $\mathrm{HBeAg}$ negative subgroups. The two groups were compared for demographic and laboratory parameters. In $\mathrm{HBeAg}$ positive patients' comparison was conducted between HBV/HDV co-infection and HBV mono-infection patients; similar comparison was performed for the HBeAg negative patients. Chisquare test and Fisher's exact test were used for categorical variables, while the independent sample test was used for numerical variables. All p-values were two sided and considered as statistically significant if $<0.05$.

\section{Results}

A total of $2455 \mathrm{HBsAg}$ positive patients were checked for HBV DNA PCR by qualitative assay; 480 (19.5\%) patients with HBV DNA PCR by qualitative assay were eligible for inclusion in this study. HBV DNA PCR quantitative assays and anti-HDV serology was checked in all these patients.

\section{Virology and HBV DNA PCR assays}

Overall, there were 398 (82.9\%) males with a mean age of $33 \pm 12.5$ years. Mean HBV DNA PCR levels was 1.9 $\times 10^{7} \pm 1.2 \times 10^{8}$ copies $/ \mathrm{ml}$. There were $169 / 480$ (35.2\%) patients with HBV/HDV co-infection.

Overall, the HBV DNA PCR assay above $1000\left(>10^{2}\right)$ copies/ml was reported in 294 (61\%) while rest have $\leq 10^{2}$ copies $/ \mathrm{ml}$. Moreover, higher HBV DNA levels of $\geq$ $10^{5}$ copies $/ \mathrm{ml}$ were found in $103(21.5 \%)$, while $<10^{5}$ in 377 (78.5\%) patients; table 1.

\section{HBeAg positive versus $\mathrm{HBeAg}$ negative patients}

Out of 480 patients, 164 (34.6\%) were HBeAg positive and 316 (65.4\%) HBeAg negative. We found that $\mathrm{HBeAg}$ 
Table 1 Characteristics of study population in $\mathrm{HBeAg}$ positive and negative patients

\begin{tabular}{|c|c|c|c|c|}
\hline & Total $n=480$ & HBeAg positive $n=164$ & HBeAg negative $n=316$ & $\mathrm{p}$ value \\
\hline Age, years & $33 \pm 12.53$ & $30 \pm 13.36$ & $34.28 \pm 11.87$ & $<0.001$ \\
\hline \multicolumn{5}{|l|}{ Gender } \\
\hline Male & 398(82.9) & 138(84.1) & $260(82.3)$ & 0.60 \\
\hline Female & $82(17.1)$ & 26(15.9) & $56(17.7)$ & \\
\hline ALT & $66.07 \pm 72.83$ & $73.95 \pm 79.04$ & $61.98 \pm 69.16$ & 0.10 \\
\hline Median ALT & $38(9-500)$ & $42(9-500)$ & $35(10-496)$ & \\
\hline Normal & $247(51.5)$ & $73(44.5)$ & $174(55.1)$ & 0.02 \\
\hline Raised & $233(48.5)$ & $91(55.5)$ & $142(44.9)$ & \\
\hline \multicolumn{5}{|l|}{ HBV DNA level } \\
\hline$\geq 10 e^{5}$ & $103(21.5)$ & $83(50.9)$ & $20(15.3)$ & $<0.001$ \\
\hline$<10 \mathrm{e}^{5}$ & $377(78.5)$ & $80(49.1)$ & $111(84.7)$ & \\
\hline \multicolumn{5}{|l|}{ Anti HDV } \\
\hline Reactive & $169(35.2)$ & $41(25)$ & $128(40.5)$ & 0.001 \\
\hline Non reactive & $311(64.8)$ & $123(75)$ & $188(59.5)$ & \\
\hline \multicolumn{5}{|l|}{ HDV RNA qualitative } \\
\hline Positive & $49(10.2)$ & $7(5.7)$ & $42(13.8)$ & $<0.001$ \\
\hline Negative & $67(14)$ & $7(5.7)$ & $60(19.7)$ & \\
\hline \multicolumn{5}{|l|}{ HBV stage } \\
\hline Carrier of HBV & $143(29.8)$ & 0 & $143(45)$ & $<0.001$ \\
\hline Chronic active HBV & $185(38.5)$ & $75(45.7)$ & $110(34.8)$ & \\
\hline Compensate cirrhosis with HBV & $72(15)$ & $22(13.4)$ & $50(15.8)$ & 0.48 \\
\hline Immunotolerant phase & $80(16.7)$ & $60(36.6)$ & $20(6.3)$ & NS \\
\hline
\end{tabular}

NS = not significant.

positive patients were younger ( $30 \pm 13.3$ years) as compared to HBeAg negative $(34.3 \pm 11.9$ years $)$; $\mathrm{p}$-value $=$ $<0.001$. ALT levels above upper limit of normal (ULN) were found in 91 (55.5\%) HBeAg positive as compared to $142(45 \%)$ among HBeAg negative group; ( $\mathrm{p}$-value = 0.02). Moreover, the level of HBV DNA PCR was $\geq 10^{5}$ copies/ml in 83 (51\%) patients with HBeAg positive as compared to 20 (15.3\%) among HBeAg negative, (pvalue $<0.001)$; table 1 .

$\mathrm{HBeAg}$ positive patients have raised ALT and higher HBV DNA levels as compared to HBeAg negative.

\section{HDV infection and ALT levels}

Mean ALT levels in our study population were $66 \pm 73$ IU. Moreover, mean ALT in patients with HBV/HDV co-infection was $74.3 \pm 76.7 \mathrm{IU}$ as compared to $61.6 \pm$ $70.3 \mathrm{IU}$ in HBV mono-infection; ( $\mathrm{p}$-value $=0.06$ ). Furthermore, there were $96 / 169(56.8 \%)$ patients with raised ALT in HBV/HDV co-infection group as compared to $137 / 311$ (44\%) in HBV mono-infection, (pvalue 0.008 ); table 2 . Overall $\mathrm{HBV} / \mathrm{HDV}$ co-infection patients have raised ALT levels.

Among $\mathrm{HBeAg}$ positive patients mean ALT was $74 \pm 79$ IU; 91/164 (55.5\%) patients had a raised ALT above the ULN. Out of 164 patients with positive $\mathrm{HBeAg}$, 41 patients had a HBV/HDV co-infection, while 123 had HBV monoinfection. Of the patients with HDV co-infection $(n=41)$, 25/41 (61\%) had raised ALT, while in patients with HBV mono-infection $(\mathrm{n}=123), 66(53.7 \%)$ patients had raised ALT level; ( $\mathrm{p}$ value $=0.41$ ); table 3 . Among patients with raised ALT, 47 (51.6\%) had HBV DNA level $\geq 10^{5}$ while $44(48.4 \%)$ had a HBV DNA level $<10^{5}$; (p-value $=0.76$ ).

Among HBeAg positive patients, HBV/HDV co-infection has no affect on ALT and HBV DNA levels.

Among HBeAg negative patients, mean ALT was $62 \pm$ 69 IU; 142/316 (45\%) had raised ALT level. 
Table 2 Clinical and laboratory parameters in HDV positive and negative patients

\begin{tabular}{|c|c|c|c|}
\hline & $\begin{array}{l}\text { HDV positive } n= \\
169\end{array}$ & $\begin{array}{l}\text { HDV negative } n= \\
311\end{array}$ & $\begin{array}{l}p \\
\text { value }\end{array}$ \\
\hline Age (years) & 32.74 & 33 & 0.88 \\
\hline Sex-male & $136(80.5 \%)$ & $262(84.2 \%)$ & 0.29 \\
\hline ALT-mean & $74.3 \pm 76.7$ & $61.6 \pm 70.3$ & 0.06 \\
\hline ALT normal & $73(43.2 \%)$ & $174(55.9 \%)$ & 0.008 \\
\hline ALT raised & $96(56.8 \%)$ & $137(44.1 \%)$ & \\
\hline HBeAg positive & $41(24.3 \%)$ & $123(39.5 \%)$ & 0.001 \\
\hline HBeAg negative & $128(75.7 \%)$ & $188(60.5 \%)$ & \\
\hline \multicolumn{4}{|l|}{$\begin{array}{l}\text { Mean HBV DNA } \\
\text { levels }\end{array}$} \\
\hline HBV DNA $>10^{5}$ & $23(13.6 \%)$ & $80(25.7 \%)$ & 0.002 \\
\hline HBV DNA $<10^{5}$ & $146(86.4 \%)$ & $231(74.3 \%)$ & \\
\hline \multicolumn{4}{|l|}{ HBV stages } \\
\hline Carrier & $45(26.6 \%)$ & $98(31.5 \%)$ & 0.003 \\
\hline Chronic active HBV & $73(43.2 \%)$ & $112(36 \%)$ & \\
\hline $\begin{array}{l}\text { Compensate } \\
\text { cirrhosis }\end{array}$ & $34(20.1 \%)$ & $38(12.2 \%)$ & 0.02 \\
\hline $\begin{array}{l}\text { Immunotolerant } \\
\text { phase }\end{array}$ & $17(10.1 \%)$ & $63(20.3 \%)$ & NS \\
\hline
\end{tabular}

In this group mean ALT was $75 \pm 79$ in $\mathrm{HBV} / \mathrm{HDV}$ co-infection as compared to $53 \pm 60.3$ among $\mathrm{HBV}$ mono-infection patients, $(\mathrm{p}$-value $=0.009)$. Moreover, ALT levels were above ULN in 71/128 (55.5\%) with $\mathrm{HBV} / \mathrm{HDV}$ co-infection as compared to $71 / 188$ (37.8\%)

Table 3 Descriptive characteristics of $\mathrm{HBeAg}$ positive patients $(n=164)$ in patients with HBV/HDV co-infection and HBV mono-infection

\begin{tabular}{llll}
\hline & $\begin{array}{l}\text { HDV Positive } \mathbf{n}= \\
\text { Age, years }\end{array}$ & $\begin{array}{l}\text { HDV } \\
\text { Negative } \\
\mathbf{n = 1 2 3}\end{array}$ & $\begin{array}{l}\mathbf{p} \\
\text { value }\end{array}$ \\
\hline Gender-male & $29 \pm 8.85$ & $\begin{array}{l}30.34 \pm \\
14.53\end{array}$ & 0.44 \\
\hline Male & $34(82.9 \%)$ & $104(84.6 \%)$ & 0.80 \\
\hline Raised ALT & $34(82.9)$ & $104(84.6)$ & 0.80 \\
\hline Mean ALT & $25(61)$ & $66(53.7)$ & 0.41 \\
\hline HBV DNA level & $72.2 \pm 70.7$ & $74.5 \pm 82$ & 0.87 \\
\hline$\geq 10 e^{5}$ & $17(41.5)$ & $66(54.1)$ & 0.17 \\
\hline$<10 e^{5}$ & $24(58.5)$ & $57(46.3)$ & \\
\hline Spectrum of HBV: & & & \\
\hline Carrier of HBV & 00 & $7(5.7)$ & 0.54 \\
\hline Chronic active HBV & $21(51.2)$ & $54(43.9)$ & NS \\
\hline Compensate cirrhosis with & $7(17.1)$ & $15(12.2)$ & NS \\
\hline HBV & & $48(39)$ & NS \\
\hline Immunotolerant phase & $12(29.3)$ & & \\
\hline NS = not significant. & &
\end{tabular}

among HBV mono-infection; (p-value =0.002); table 4 . Among patients with raised ALT, 12 (8.5\%) had a HBV DNA level $\geq 10^{5}$ while $130(91.5 \%)$ had a HBV DNA level $<10^{5}$ copies $/ \mathrm{ml}$ (p-value $=0.16$ ).

Among $\mathrm{HBeAg}$ negative patients, $\mathrm{HBV} / \mathrm{HDV}$ co-infection is associated with raised ALT levels, but ALT levels were not directly proportionate to HBV DNA levels.

\section{HDV infection and HBeAg status}

A large proportion of patients with HBV/HDV co-infection had HBeAg negative $(128 / 169 ; 75.7 \%)$ disease, as compared to HBV mono-infection (188/311; 60.5\%); p-value 0.001 .

Among HBeAg positive patients, 41/169 (24.3\%) had HBV/HDV co-infection. The distribution of age, gender, ALT and HBV DNA PCR levels were similar among the two groups. Furthermore, the spectrum of hepatitis B disease was also similar in both groups; table 3.

$\mathrm{HBV} / \mathrm{HDV}$ co-infection has no implications on the HBV DNA PCR as well as the spectrum of liver disease. Table 3; Figure 1.

Among HBeAg negative patients, 128/316 (40.5\%) had HBV/HDV co-infection. HBV DNA PCR levels were equally distributed in the two groups of patients (table 2). Patients with $\mathrm{HBV} / \mathrm{HDV}$ co-infection had more severe liver disease - compensated liver cirrhosis was present in

Table 4 Descriptive characteristics of $\mathrm{HBeAg}$ negative patients $(n=316)$ in patients with HBV/HDV co-infection and HBV mono-infection

\begin{tabular}{|c|c|c|c|}
\hline & $\begin{array}{l}\text { HDV Positive } n= \\
128\end{array}$ & $\begin{array}{l}\text { HDV } \\
\text { Negative } \\
n=188\end{array}$ & $\begin{array}{l}\mathrm{p} \\
\text { value }\end{array}$ \\
\hline Age, years & $34 \pm 11.3$ & $34.5 \pm 12.2$ & 0.63 \\
\hline Gender-Male & 102(79.7) & $158(84)$ & 0.32 \\
\hline Raised ALT & $71(55.5)$ & $71(37.8)$ & 0.002 \\
\hline HBV DNA Positive & $41(32.3)$ & 74(39.4) & 0.20 \\
\hline \multicolumn{4}{|l|}{ HBV DNA level } \\
\hline$\geq 10 \mathrm{e}^{5}$ & $6(11.5)$ & $14(17.7)$ & 0.32 \\
\hline$<10 e^{5}$ & 122(95.3) & 174(92.6) & \\
\hline Cirrhosis & $27(21.1)$ & 23(12.2) & 0.03 \\
\hline \multicolumn{4}{|l|}{ HBV stage } \\
\hline Carrier of HBV & $44(34.4)$ & $92(48.9)$ & 0.009 \\
\hline Chronic active HBV & $52(40.6)$ & $58(30.9)$ & \\
\hline $\begin{array}{l}\text { Compensate cirrhosis with } \\
\text { HBV }\end{array}$ & $27(21.1)$ & $23(12.2)$ & NS \\
\hline Immunotolerant phase & $5(3.9)$ & 15(8) & NS \\
\hline
\end{tabular}




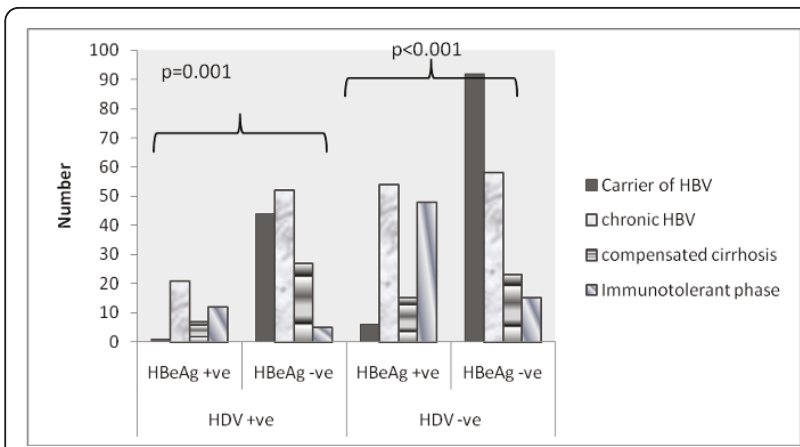

Figure 1 Comparison of spectrum of hepatitis $B$ related liver diseases in patients with HBV/HDV co-infection and HBV mono-infection, based on $\mathrm{HBeAg}$ status.

27 (21\%) as compared to 23 (12\%) among HBV monoinfection; $\mathrm{p}$-value $=0.03$. Similarly, chronic active hepatitis $(\mathrm{CAH})$ in $52(40.6 \%)$ patients with $\mathrm{HBV} / \mathrm{HDV}$ coinfection as compared to $58(31 \%)$ without it; (p-value = 0.009); table 4; Figure 1

Among $\mathrm{HBeAg}$ negative patients with $\mathrm{HBV} / \mathrm{HDV}$ coinfection, severe form of liver disease is seen, though HBV DNA levels were equally distributed, suggesting that HDV is actively involved in the progression of liver disease.

\section{HDV infection and HBV DNA quantitative assays}

Overall levels of HBV DNA PCR $<10^{5}$ was found in 146 (86.4\%) HBV/HDV co-infected patients as compared to 231 (74.3\%) HBV mono-infection (p-value = $0.002)$; table $1 \mathrm{~b}$. However, this suppression of $\mathrm{HBV}$ DNA levels in $\mathrm{HBV} / \mathrm{HDV}$ co-infection patients was independent of the HBeAg status; table $3 \& 4$ and Figure $2 \& 3$.

This suggests presence of HBV/HDV co-infection suppresses HBV DNA levels.

\section{HDV infection and clinical spectrum}

The details of demographics, baseline laboratory parameters and distribution of spectrum of hepatitis $B$ related liver disease is shown in table 1 . There were $73 /$ 169 (43\%) patients with chronic active hepatitis B (CAH) among HBV/HDV co-infection as compared to 112/311 (36\%) among HBV mono-infection; ( $\mathrm{p}$-value = 0.003). Similarly there were $34(20 \%)$ patients with compensated liver cirrhosis (CLC) among HBV/HDV coinfection as compared to $38(12 \%)$ in HBV mono-infection group; $\mathrm{p}$-value $=0.02$. We found most asymptomatic carrier and immune-tolerant hepatitis $B$ patients in HBV mono-infection group (table 1). HBV/HDV coinfection produces more severe clinical spectrum of liver disease. Moreover, this impact of $\mathrm{HBV} / \mathrm{HBV}$ co-infection is more marked in HBeAg negative patients as already mentioned above.

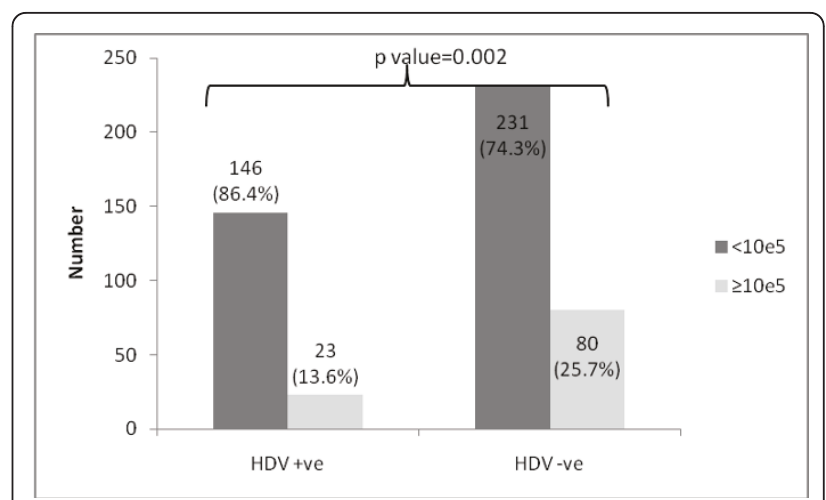

Figure 2 Showing significant HBV DNA levels suppression in patients with HBV/HDV co-infection.

\section{Discussion}

This is the largest report that we know on viral characteristics of hepatitis delta virus infection, recruited at two centers of Pakistan which represent a robust population of South Asia. In particular, data of HBeAg positive patients is limited globally. HBV patients can be simultaneously infected by delta virus, as the source of transmission of both viruses is same and results in a severe form of liver disease. There are variable reports, as to which virus is actively responsible for liver disease in patients with chronic HDV infection - HBV or HDV? [14-17]. We designed this study to examine the effects of $\mathrm{HBV} / \mathrm{HDV}$ co-infection on ALT, HBeAg status and HBV DNA PCR levels, in addition to the different spectrums of hepatitis B related liver disease. Our present study showed that $35.2 \%$ of patients had HBV/HDV coinfection. We published an epidemiological survey of HDV prevalence in 2005. This survey included 8721 HBV patients over 14 years of age and tested for antiHDV antibody from all over the country. The HDV

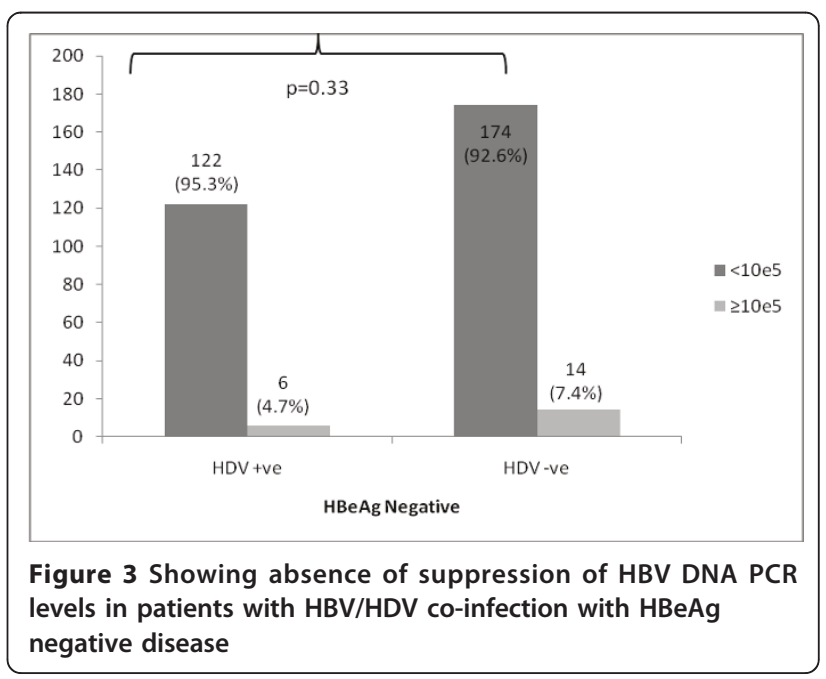


prevalence was found to be $16.6 \%$ [9]. Higher frequency of HDV co-infection in this report could have been due to a selection bias as reported by Seetlani et al [24].

In our present study, majority of patients with $\mathrm{HBV} /$ HDV co-infection were young males, which is similar to earlier studies from Italy [25], and Pakistan [9]. One possible explanation could be the higher rate of intravenous drug abuse in this cohort of patients in the developed countries, and therapeutic injections with contaminated needles and vertical transmission in the developing world [26]. The mean age of cirrhotic HDV patients was also younger than that of cirrhotic HBV patients without HDV. These findings indicate the greater severity of chronic HDV infection than chronic HBV infection alone.

Our study shows that patients with HBV/HDV coinfection have raised ALT levels and suppressed HBV DNA levels as compared to HBV mono-infection. Moreover, HBV patients with HBeAg positive disease regardless of their HDV status have raised ALT levels and high HBV DNA levels as compared to HBeAg negative patients. Interestingly, we observed that in $\mathrm{HBeAg}$ positive patients, ALT and HBV DNA levels were equally distributed among HBV/HDV co-infection and HBV mono-infection patients. It seems that among $\mathrm{HBeAg}$ positive patients HBV/HDV co-infection has no impact on the HBV DNA levels.

Contrary to $\mathrm{HBeAg}$ positive group, among $\mathrm{HBeAg}$ negative patients HBV/HDV co-infection is associated with raised ALT levels, but ALT levels were not correlated to high HBV DNA levels. Among $\mathrm{HBeAg}$ negative patients with HBV/HDV co-infection, a more severe spectrum of liver disease was seen, although the HBV DNA level was low. This would suggest that HDV is actively involved in progress of liver disease.

Our study also shows that HBV/HDV co-infection, suppresses hepatitis B virus. HBV/HDV co-infection produces a more aggressive disease as compared to mono-infection with hepatitis B. This has also been reported in many studies [14-16,23] for HBeAg negative patients.

Furthermore, HBeAg, a marker of viral replication, was found in a higher percentage of patients with HBV mono-infection as compared to HBV/HDV co-infection, which was also noted in our study. It has also been well documented that the difference in HBV genotype affects the prevalence of $\mathrm{HBeAg}$ and the replication level of HBV $[27,28]$. HBV genotype B is reported to be associated with $\mathrm{HBeAg}$ negativity and a lower viremia level. Furthermore, certain HDV strains, like HDV genotype II are associated with more mild liver disease. Correlation between HDV genotypes and HBV replication however remains largely unknown.
The main mechanism of inhibition of viral replication in HBV infection is not cytotoxicity against infected hepatocytes but rather the secretion of inhibitory cytokines like interferon-gamma, interferon-alpha or TNFalpha. HDV proteins inhibit HBV replication by transrepressing its enhancers and by trans-activating the IFN-alpha-inducible MxA gene [29].

Individuals having HBV/ HDV co-infection may have a more severe acute disease and higher risk of fulminant hepatitis [14-16]. It is observed that most of the individuals infected with HDV develop the chronic form of the disease, and in approximately $80 \%$ of these individuals the chronic HDV infection progresses to cirrhosis within 5-10 years [30]. This observation is also noted in our HBV/HDV co-infection patients. HBV/HDV coinfection showed a several fold increase in progression of chronic hepatitis to cirrhosis (p-value 0.003) as compared to HBV mono-infection.

In conclusion, we found that HBV/HDV co-infection results in suppression of hepatitis $B$ virus. Patients with $\mathrm{HBV} / \mathrm{HDV}$ co-infection with negative $\mathrm{HBeAg}$ status demonstrate a severe spectrum of liver disease. Due to limited and ineffective treatment options for the treatment of HBV/HDV infection our main focus must be on the prevention of the disease. While the prevalence of HDV is showing a decreasing trend globally, it is important to realize that globalization and increasing migratory fluxes are major challenges and HDV will not be controlled adequately unless HBV is brought under control in areas with high prevalence.

\section{Acknowledgements}

We would like to acknowledge Ms. Safia Awan who helped us in the statistical analysis of the data.

\section{Author details}

${ }^{1}$ Section of Gastroenterology, Department of Medicine, Aga Khan University Hospital, Stadium Road, PO Box \# 74800, Karachi, Pakistan. ${ }^{2}$ Isra University Hospital, Hala Road, PO Box 313, Hyderabad, Pakistan. ${ }^{3}$ Department of Molecular Biology, Aga Khan University Hospital, Stadium Road, PO Box \# 74800, Karachi, Pakistan.

\section{Authors' contributions}

KM contributed in terms of original idea, study design, writing protocol, organizing logistics, and editing the article. USA and SM contributed to study design, logistics, caring for patients under study and editing the article. AK and MTU contributed by collecting data, literature search, writing of the article with first two authors. TM, SH and WJ contributed in study design, care of study patients, and editing of the article. All authors read and approved the final manuscript.

\section{Competing interests}

The authors declare that they have no competing interests.

Received: 24 December 2010 Accepted: 20 June 2011

Published: 20 June 2011

\section{References}

1. Taylor JM: Hepatitis delta virus. Virology 2006, 344:71-76. 
2. Hadziyannis SJ: Review: hepatitis delta. J: Gastroenterol Hepatol 1997, 12:289-298.

3. Caturelli E, Castellano L, Fusilli S, et al: Coarse nodular US pattern in hepatic cirrhosis: risk for hepatocellular carcinoma. Radiology 2003, 226:691-697.

4. Rizzetto M, Purcell RH, Gerin JL: Epidemiology of HBV associated delta agent: geographical distribution of antidelta and prevalence in polytransfused HBsAg carriers. Lancet 1980, 1:1215-18.

5. Cotrina M, Buti M, Jardi R, et al: Hepatitis delta genotypes in chronic delta infection in the northeast of Spain (Catalonia). J Hepatol 1998, 28:971-7.

6. Stroffolini $T$, Ferrigno $L$, Chialdea $L$, et al: Incidence and risk factors of acute delta hepatitis in Italy: results from a national surveillance system. J Hepatol 1994, 21:1123-6.

7. Gaeta GB, Stroffolini T, Chiaramonte M, et al: Chronic hepatitis D: a vanishing disease? An Italian multicenter study. Hepatology 2000, 32:824-7.

8. Degertekin $\mathrm{H}$, Yalcin $\mathrm{K}$, Yakut M: The prevalence of hepatitis delta virus infection in acute and chronic liver diseases in Turkey: an analysis of clinical studies. Turk J Gastroenterol 2006, 17:25-34.

9. Mumtaz K, Hamid SS, Adil S, et al: Epidemiology and clinical pattern of hepatitis delta virus infection in Pakistan. J Gastroenterol Hepatol 2005, 20:1503-1507.

10. Abbas Z, Jafri W, Raza S: Hepatitis D: Scenario in the Asia-Pacific region. World J Gastroenterol 2010, 16(5):554-562.

11. CW Su, Huang YH, Huo Tl, et al: Genotypes and viremia of hepatitis B and $D$ viruses are associated with outcomes of chronic hepatitis $D$ patients. Gastroenterology 2006, 130:1625-1635.

12. Moatter T, Abbas Z, Shabir S, et al: Clinical presentation and genotype of hepatitis delta in Karachi. World J Gastroenterol 2007, 13:2604-2607.

13. Mumtaz K, Hamid S, Ahmed S, et al: A study of genotypes, mutants and nucleotide sequence of hepatitis B virus in Pakistan. Hepatitis Monthly 2011, 11(1):25-29.

14. Sakugawa $H$, Nakasone $H$, Nakayoshi $T$, et al: Hepatitis B virus concentrations in serum determined by sensitive quantitative assays in patients with established chronic hepatitis delta virus infection. $J$ Med Virol 2001, 65:478-484.

15. Yamashiro T, Nagayama K, Enomoto N, et al: Quantification of the level of hepatitis delta virus RNA in serum, by real-time polymerase chain reaction - and its possible correlation with the clinical stage of liver disease. J Infect Dis 2004, 189:1151-1157.

16. Hadziyannis SJ, Sherman M, Liberman HM, et al: Liver disease activity and hepatitis $B$ virus replication in chronic hepatitis delta antigen-positive hepatitis B virus carriers. Hepatology 1985, 5:544-547.

17. Su CW, Huang YH, Huo Tl, et al: Genotypes and viremia of hepatitis B and $\mathrm{D}$ viruses are associated with outcomes of chronic hepatitis $\mathrm{D}$ patients. Gastroenterology 2006, 130:1625-1635.

18. Rodriguez $F$, Buti $M$, et al: Role of hepatitis $B, C$, and $D$ viruses in dual and triple infection: influence of viral genotypes and hepatitis $B$ precore and basal core promoter mutations on viral replicative interference. Hepatology 2001, 34:404-410.

19. Coppola N, Scolastico C, et al: Virologic and clinical expressions of reciprocal inhibitory effect of hepatitis $B, C$, and delta viruses in patients with chronic hepatitis. Hepatology 2000, 32:1106-1110.

20. Flodgren $\mathrm{E}$, Bengtsson $\mathrm{S}$, Knutsson $\mathrm{M}$, et al: Recent high incidence of fulminant hepatitis in Samara, Russia: molecular analysis of prevailing hepatitis B and D virus strains. J Clin Microbiol 2000, 38(9):3311-6.

21. Lok AS, Heathcote EJ, Hoofnagle JH: Management of hepatitis B: 2000summary of a workshop. Gastroenterology 2001, 120:1828-1853

22. Fattovich G, Bortolotti F, Donato F: Natural history of chronic hepatitis B: special emphasis on disease progression and prognostic factors. J Hepatology 2008, 48:335-352.

23. Heidrich B, Deterding K, Tillmann HL, et al: Virological and clinical characteristics of delta hepatitis in Central Europe. Journal of Viral Hepatitis 2009, 16:883-894.

24. Seetlani NK, Abbas Z, Raza S, et al: Prevalence of hepatitis D in HBsAg positive patients visiting liver clinics. J Pak Med Assoc 2009, 59:434-437.

25. Giovanni BG, Tommaso S, Maria $C$ et al: A vanishing disease? An Italian Multicentre Study. Hepatology 2000, 32:824-7.

26. Luby SP, Qamaruddin K, Shah AA, et al: The relationship between therapeutic injections and high prevalence of hepatitis $\mathrm{C}$ infection in Hafizabad Pakistan. Epidemiol Infect 1997, 119:349-56.
27. Lindh $M$, Horal $P$, Dhillon AP, et al: Hepatitis B virus DNA levels, precore mutations, genotypes and histological activity in chronic hepatitis B. J Viral Hepat 2000, 7:258-267.

28. Orito E, Mizokami M, Sakugawa $H$, et al: A case-control study for clinical and molecular biological differences between hepatitis $B$ viruses of genotypes B and C. Japan HBV Genotype Research Group. Hepatology 2001, 33(1):218-223.

29. Williams $V$, Brichler $S$, Radjef $N$, et al: Hepatitis delta virus proteins repress hepatitis $B$ virus enhancers and activate the alpha/beta interferoninducible MxA gene. J Gen Virol 2009, 90:2759-67.

30. Fattovich G, Boscaro $S$, Noventa F, et al: Influence of hepatitis delta virus infection on progression to cirrhosis in chronic hepatitis type B. J Infect Dis 1987, 155:931-935.

doi:10.1186/1743-422X-8-312

Cite this article as: Mumtaz et al:: Virological and clinical characteristics

of hepatitis delta virus in South Asia. Virology Journal 2011 8:312.

\section{Submit your next manuscript to BioMed Central and take full advantage of:}

- Convenient online submission

- Thorough peer review

- No space constraints or color figure charges

- Immediate publication on acceptance

- Inclusion in PubMed, CAS, Scopus and Google Scholar

- Research which is freely available for redistribution
Ciomed Central 